\title{
Invited review: Bioactive compounds produced during cheese ripening and health effects associated with aged cheese consumption
}

\author{
Lourdes Santiago-López,, ${ }^{* 1}$ Jose E. Aguilar-Toalá, ${ }^{* 1}$ Adrián Hernández-Mendoza, ${ }^{*}$ Belinda Vallejo-Cordoba, ${ }^{*}$ \\ Andrea M. Liceaga, $†$ and Aarón F. González-Córdova*2 \\ *Laboratorio de Química y Biotecnología de Productos Lácteos, Coordinación de Tecnología de Alimentos de Origen Animal, \\ Centro de Investigación en Alimentación y Desarrollo, A. C. (CIAD), Hermosillo, Sonora 83304, México \\ †Department of Food Sciences, Purdue University, West Lafayette, IN 47907
}

\section{ABSTRACT}

Traditionally, cheese is manufactured by converting fluid milk to a semisolid mass through the use of a coagulating agent, such as rennet, acid, heat plus acid, or a combination thereof. Cheese can vary widely in its characteristics, including color, aroma, texture, flavor, and firmness, which can generally be attributed to the production technology, source of the milk, moisture content, and length of aging, in addition to the presence of specific molds, yeast, and bacteria. Among the most important bacteria, lactic acid bacteria (LAB) play a critical role during the cheese-making process. In general, LAB contain cell-envelope proteinases that contribute to the proteolysis of cheese proteins, breaking them down into oligopeptides that can be subsequently taken up by cells via specific peptide transport systems or further degraded into shorter peptides and amino acids through the collaborative action of various intracellular peptidases. Such peptides, amino acids, and their derivatives contribute to the development of texture and flavor in the final cheese. In vitro and in vivo assays have demonstrated that specific sequences of released peptides exhibit biological properties including antioxidant, antimicrobial, anti-inflammatory, immunomodulatory, and analgesic/opioid activity, in addition to angiotensin-converting enzyme inhibition and antiproliferative activity. Some LAB also produce functional lipids (e.g., conjugated linoleic acid) with anti-inflammatory and anticarcinogenic activity, synthesize vitamins and antimicrobial peptides (bacteriocins), or release $\gamma$-aminobutyric acid, a nonprotein amino acid that participates in physiological functions, such as neurotransmission and hypotension induction, with diuretic effects. This review provides an overview

\footnotetext{
Received July 9, 2017.

Accepted January 9, 2018.

${ }^{1}$ These authors contributed equally to this paper.

${ }^{2}$ Corresponding author: aaronglz@ciad.mx
}

of the main bioactive components present or released during the ripening process of different types of cheese. Key words: cheese, bioactive compound, multifunctional activities, health effect

\section{INTRODUCTION}

Cheese, defined as the fresh or matured product obtained from the coagulation of milk, is easily digestible and rich in nutritional components, thus constituting an important source of proteins, short-chain fatty acids, vitamins, and minerals. It is therefore an important source of a wide variety of biologically active substances (Walther et al., 2008; Diana et al., 2014). Cheese can be classified based on the type of milk used, manufacturing process, fat content, type of fermentation, and its microbiota (Walther et al., 2008).

Several compounds in cheese are derived from the metabolism of lactic acid bacteria ( $\mathbf{A} \mathbf{A B})$, which play an important role in the cheese-making process and contribute to the development of the texture and flavor of the final product. Lactic acid bacteria hydrolyze lactose during fermentation and produce high concentrations of lactic acid and other organic acids (Settanni and Moschetti, 2010). Several milk enzymes, such as rennet and enzymes from LAB, participate in the ripening process, resulting in the subsequent transformations that target the diverse constituents of curds (Leroy and De Vuyst, 2004; McSweeney, 2004).

The following bioactive compounds are found in cheese: peptides, exopolysaccharides, fatty acids, organic acids, vitamins, $\gamma$-aminobutyric acid (GABA), and CLA. All of these have biological activities. In vitro and in vivo studies have demonstrated that these compounds inhibit angiotensin-converting enzyme (ACE) and exhibit antioxidant, antimicrobial, and antiproliferative activities (Faure et al., 2006; Sprong et al., 2010; Geurts et al., 2012). The above bioactivities lead to health-protective effects associated with a reduced incidence of cardiovascular disease risk factors, such as 
obesity, dyslipidemia, and type 2 diabetes (Sullivan et al., 2001), as well as reduced incidence of metabolic syndrome (MetS; Bonthuis et al., 2010; Sonestedt et al., 2011). Mexican cheeses have potential benefits because of their native microflora, the type of milk used, and artisanal techniques applied during their production. A previous study (Torres-Llanez et al., 2011) demonstrated the ACE-inhibitory action of peptides derived from fresh cheese and a model cheese (made at the laboratory scale). Studies in Mexico on bioactive compounds present in artisanal cheeses are limited, and those available focus primarily on the antioxidant and ACE activity of water-soluble extracts (WSE) obtained from different types of artisanal cheese (e.g., Crema de Chiapas, Cocido, and Fresco of Sonora) from different storage conditions (Aguilar-Toalá et al., 2013, 2015; Santos-Espinosa et al., 2013).

This review article provides an overview of the main bioactive components present or released during the ripening process of different cheese types from different countries.

\section{INFLUENCE OF CHEESE PROCESSING TECHNOLOGY ON THE DEVELOPMENT OF BIOACTIVE COMPOUNDS}

Cheese is a biologically and biochemically dynamic product, in which a series of sequential changes take place during the cheese-making process. Some technological procedures such as heat treatment, homogenization, pressure application, and milk coagulation can affect the structure of the milk constituents and promote the development or the release of bioactive compounds (Kumar et al., 2006; Cruz et al., 2011).

Some studies have reported that heat treatments alter the final milk and cheese composition and thereby determine cheese quality (Albenzio et al., 2001; McSweeney, 2004). Meanwhile, other authors have hypothesized that pasteurization could influence the amount of protein and PUFA in milk or cheese; however, the results of a study showed that heat treatment did not affect the amount of protein or the fatty acid profile of cheese (Cuchillo-Hilario et al., 2010). Albenzio et al. (2001) reported that heat affected the content of water-soluble $\mathrm{N}$ and total $\mathrm{N}$, which were higher in cheese made with raw milk than in cheese made with pasteurized or raw milk (heat treatment of curds at $80^{\circ} \mathrm{C}$ for $30 \mathrm{~s}$ in hot whey). Thus, temperature conditions can affect the amount and specific sequence of bioactive peptides. Changes to proteins are generally related to their functional properties and are favored by the action of enzymes specific to milk. Additionally, the microorganisms present or added during cheese-making may release bioactive compounds (Claeys et al., 2012).
Proteases and peptidases present in milk (e.g., plasmin, cathepsin D) lead to formation of large and intermediate-sized peptides; subsequently, these peptides are further hydrolyzed by residual coagulant retained in the curd and finally, by enzymes from the cheese starter and the nonstarter microbiota. This set of reactions is known as primary proteolysis. Of the enzymes present in milk, the enzyme that mainly contributes to proteolysis is plasmin. Plasmin is extremely thermostable, and its activity increases after heat treatment, either by inactivation of natural plasmin inhibitors or the activation of plasminogen in milk during heating (Chavan et al., 2011). Thus, pasteurization or milk heating during cheese manufacture can enhance the formation of peptides. Moatsou et al. (2008) found that the activity of plasmin decreased directly related to increased temperature and pressure during the cheese-making process. The combination of both factors (temperature and pressure) on reduction of plasmin activity is desirable because of the effect on cheese yield, proteolysis, and quality milk during storage. In contrast, the activity of another proteolytic enzyme, cathepsin D, is mostly suppressed following pasteurization and whey drainage (McSweeney, 2004).

Paul et al. (2012) found that the high pressure and temperature applied during the packaging of fresh cheese affected the antioxidant activity [evaluated by the oxygen radical absorbance capacity (ORAC) method] of water-soluble proteins containing bioactive peptides. The lowest antioxidant activity [10.2 Trolox equivalents (TE)/g of cheese) was for cheese processed at $600 \mathrm{MPa}$ for $20 \mathrm{~min}$ at $22^{\circ} \mathrm{C}$; meanwhile, for cheese processed at $400 \mathrm{MPa}$ for $10 \mathrm{~min}$ at $22^{\circ} \mathrm{C}$, the antioxidant activity was $67.6 \mathrm{TE} / \mathrm{g}$. In this sense, the length of processing time and pressure used can affect the antioxidant activity of fresh cheese.

Another study showed that the application of high hydrostatic pressure to Garrotxa cheese (400 MPa, 5 min, $14^{\circ} \mathrm{C}$ ) affected lipolysis and generated a cheese with lower amounts of free fatty acids. This can be attributed to the resulting decrease of microorganisms or the inactivation of lipolytic enzymes of the secondary microbiota (Saldo et al., 2003).

\section{ROLE OF RIPENING AND LAB ON THE PRODUCTION OF BIOACTIVE COMPOUNDS}

In the complex microbial niche of cheese, LAB, yeast, and some molds are present. These microbes play an important role in the development of the sensory characteristics of cheese and in the technological aspects of cheese production (Irlinger and Mounier, 2009).

During the cheese-making process, LAB can be added as a starter culture, contributing to the coagulation 


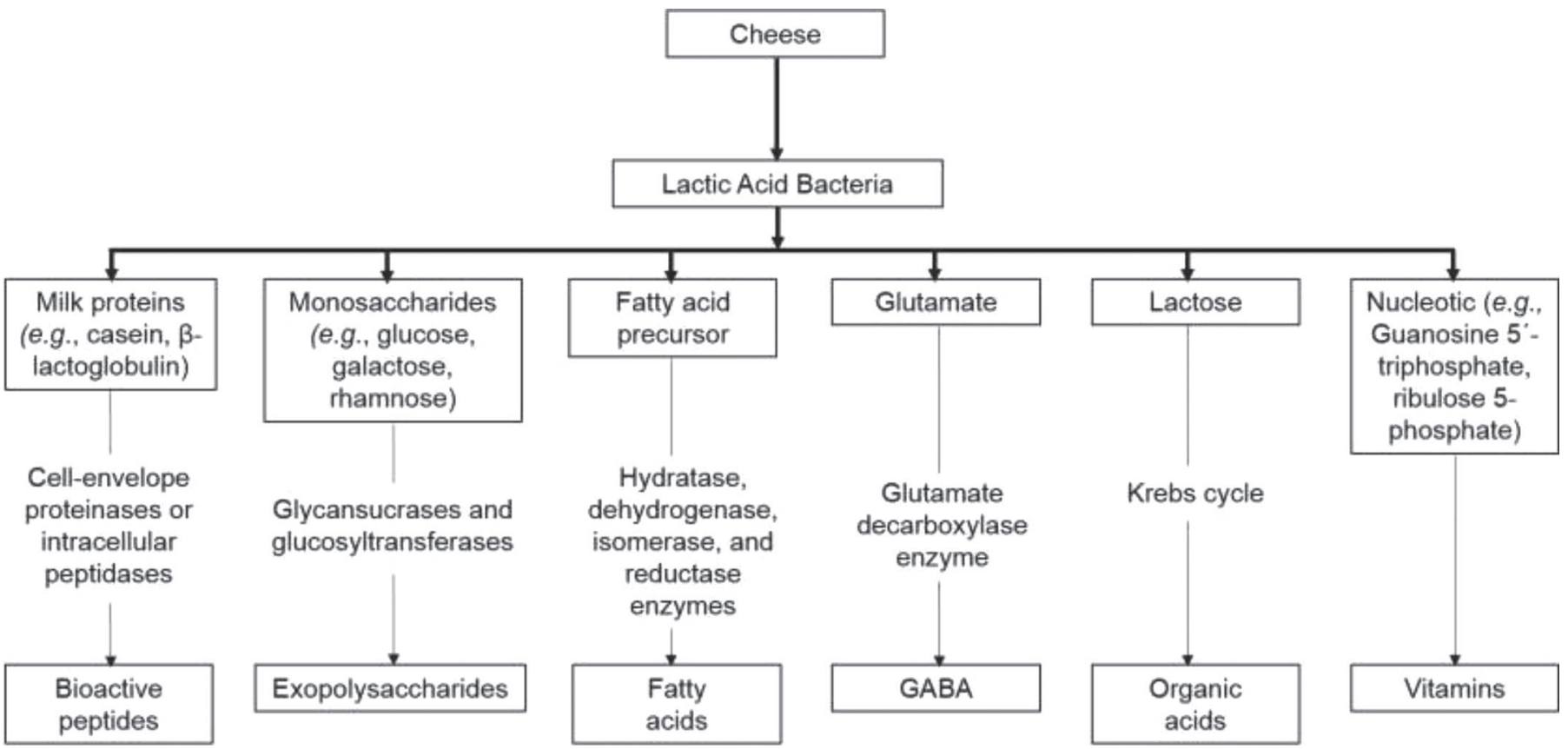

Figure 1. The role of lactic acid bacteria during the fermentation or ripening process of cheese. Lactic acid bacteria have been documented as precursors of bioactive compounds, and their action releases peptides, exopolysaccharides, fatty acids, $\gamma$-aminobutyric acid (GABA), organic acids, and vitamins. Different mechanisms and factors are involved during the release of bioactive compounds, including enzymes, $\mathrm{pH}$ conditions, ripening time, and temperature.

of caseins (Grattepanche et al., 2008; González et al., 2010; Yang et al., 2012). On the other hand, at least one group of nonstarter LAB (NSLAB; e.g., lactobacilli, pediococci, enterococci, and Leuconostoc) can also be present naturally in cheese. The main source of NSLAB is raw milk, although other cheese ingredients or equipment can also be a source and therefore enhance their concentration in the final product. The NSLAB grow at a very low rate during the first weeks of ripening but eventually dominate the cheese microbiota after the death phase of the starter culture (Casey et al., 2006; Zuljan et al., 2016). Both groups of LAB are important for the development of the biochemical characteristics of fresh cheese and for cheese ripening. During the ripening process, LAB release bioactive peptides, EPS, vitamins, CLA, GABA, and oligosaccharides (Figure 1; (Beermann and Hartung, 2013).

\section{Bioactive Peptides}

As mentioned above, the release of bioactive peptides has been documented during cheese ripening (Mao et al., 2007; Phelan et al., 2009; Hernandez-Ledesma et al., 2011). For example, rennet-coagulated cheeses are ripened for periods ranging from 2 wk for Mozzarella, to 2 or more years for Parmigiano-Reggiano and Cheddar cheese. During this time, microbiological and biochemical changes in the curd take place, resulting in characteristic flavors and textures of particular varieties (McSweeney, 2004).

Cheese ripening is a complex, dynamic system. In this process, the diversity of proteolytic enzymes naturally present in milk and the residual coagulants, as well as the enzymatic metabolism of LAB, play an essential role (Gagnaire et al., 2001) in the final cheese. During ripening, peptides are being constantly released by the action of plasmin and enzymes from LAB; some of these peptides are subsequently hydrolyzed, whereas others accumulate during storage (Ryahanen et al., 2001; Ong et al., 2007).

Bioactive peptides that are encrypted or inactivated in the protein matrix can be released by enzymatic hydrolysis (e.g., pepsin, trypsin, and chymotrypsin) during gastrointestinal digestion, or by the action of proteases and peptidases released by LAB (Fitzgerald and Murray, 2006). Peptides generally consist of sequences of 3 to $20 \mathrm{AA}$. Some are resistant to the digestive action of peptidases and are then absorbed and passed through to the bloodstream (Kitts and Weiler, 2003).

Three major components are involved in proteolysis by LAB: (1) cell wall-envelope proteinases (CEP) that initiate the degradation of extracellular casein into oli- 
gopeptides; (2) peptide transporters that take up peptides into the cell; and (3) intracellular peptidases that degrade peptides into shorter peptides and AA (Liu et al., 2010). Five types of CEP have been characterized, and all have a strong preference for hydrophobic caseins. These caseins contain a large number of Pro residues that prevent the formation of random coils, thereby encouraging the action of CEP on them (Savijoki et al., 2006). The proteolysis process releases peptides with specific bioactivities, including antimicrobial, antihypertensive, immunomodulatory, analgesic, and antioxidant activities that can positively affect major human body systems (e.g., cardiovascular, digestive, immune, and nervous systems; Table 1) (Hartmann and Meisel, 2007; Gupta et al., 2009).

Several studies have reported the antioxidant activity of bioactive peptides found in Cheddar (Gupta et al., 2009; Pritchard et al., 2010), Coalho (Silva et al., 2012), Fresco (Paul et al., 2012), Parmigiano-Reggiano (Bottesini et al., 2013), and cottage cheese (AbadíaGarcía et al., 2013). Gupta et al. (2009) evaluated the antioxidant activity of WSE of Cheddar cheese made with and without adjunct cultures at different stages of ripening. The results showed that the antioxidant activity was dependent on the ripening stage. 2,2'-Azino-bis(3-ethylbenzothiazoline-6-sulfonic acid) (ABTS) radical scavenging activity increased for Cheddar cheese manufactured with adjunct cultures and showed the highest activity during the fourth month of ripening (16.61 and $9.76 \mu \mathrm{mol}$ of $\mathrm{TE} / \mathrm{mg}$ of protein, for Cheddar cheese made with and without adjunct culture, respectively); the Trolox-equivalent antioxidant capacity (TEAC) showed a steady increase as ripening proceeded and reached a maximum value $(9.81 \mu \mathrm{mol}$ of $\mathrm{TE} / \mathrm{mg}$ of protein) during the fourth month. The same results were observed for 2,2-diphenyl-1-picrylhydrazyl (DPPH) radical scavenging activity, which increased up to the fourth month of ripening. After that, antioxidant activity decreased in the fifth month, indicating that antioxidant peptides at this stage were not resistant to further proteolysis (Gupta et al., 2009; Pritchard et al., 2010).

The antioxidant capacity of Parmigiano-Reggiano cheese was unaffected by ripening time (7-41 mo). This is likely due to the presence of free AA and only in part to the release of peptides (Bottesini et al., 2013). However, free AA are not effective antioxidants (Elias et al., 2008). The effectiveness of peptides compared with free $\mathrm{AA}$ is attributed to the unique chemical and physical properties conferred by their sequences, especially the stability of resultant peptide radicals that do not initiate or propagate oxidative reactions (Samaranayaka and Li-Chan, 2011).
The peptide profiles of Coalho cheese obtained from different towns in Brazil were evaluated for antioxidant (ABTS radical scavenging), zinc-binding, and antimicrobial activities. Results showed that the cheese from Correntes had the highest antioxidant value (91.1\%) compared with cheese from other towns: Cachoeirinha (85.9\%), Arcoverde (84.2\%), Sao Bento do Una (77.9\%), Capoeiras (87.8\%), and Venturosa (82.8\%). Zinc-binding activity is important because cheese intake can enhance the bioavailability of zinc. Silva et al. (2012) showed that Coalho cheese had zinc-binding activity ranging from $61.8 \%$ (cheese from Capoeiras) to $75.5 \%$ (cheese from Correntes). Meanwhile, antimicrobial activity was effective against Enterococcus faecalis ATCC 6057, Bacillus subtilis ATCC 6633, Escherichia coli ATCC 25922, and Pseudomonas aeruginosa ATCC 27853 for the cheese obtained from Cachoeirinha and Venturosa (Silva et al., 2012). The main changes could be attributed to the action of the microbiota, as well as to the making process of each type of cheese, modifying the proteolytic activity and sequence of AA that could be responsible for their activity.

The antioxidant activity of water-soluble extracts of Feta, Roquefort-type, and Pecorino-type cheese from Brazil and Pecorino Sardo-type and Cerrillano from Uruguay were evaluated in another study (Meira et al., 2012). The results showed ABTS radical scavenging capacity of 32 to $45 \%$ and $87 \%$ with respect to control for Feta and Roquefort-type cheeses, respectively. Iron chelating activity was variable, yet Pecorino cheese showed the highest activity. The thiobarbituric acid reactive substances (TBARS) analysis showed similar activities ranging from 25 to $51 \%$ among the evaluated cheeses. The DPPH radical scavenging activity was highest for Roquefort-type cheese. Another measure of bioactivity was the ACE inhibitory activity: Feta and Roquefort-type cheeses showed the greatest activity (46 and $80 \%$, respectively). However, none of the watersoluble extracts from the cheese showed antimicrobial activity. Peptides from the Roquefort-type cheese had a sequence of YQGPIVLNPWDQVKR, corresponding to $\alpha_{S 2}$-casein. The peptides released in this cheese coincided with milk peptides shown to have different bioactivities. These results suggest the presence of bioactive peptides with multifunctional activity and different modes of action and highlight the importance of ripening time (Meira et al., 2012).

The ACE-inhibitory activity of other cheeses including Mozzarella, Italico (Smacchi and Gobbetti 1998), red Cheddar, Camembert (Okamoto et al., 1995), Gouda, Emmental (Saito et al., 2000), Manchego, Ronca, and goat cheeses (Gómez-Ruiz et al., 2006) has also been studied. For example, ACE-inhibitory pep- 


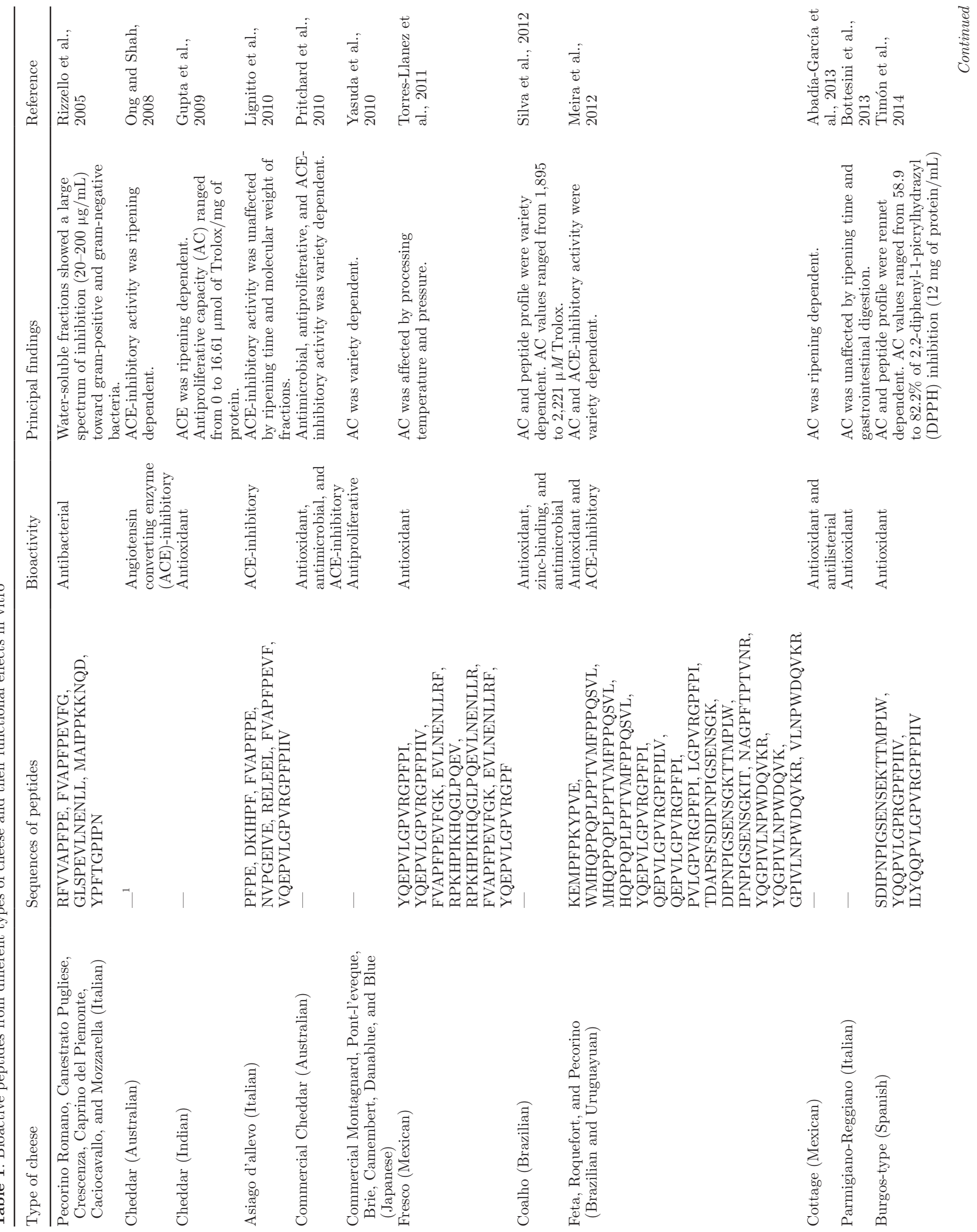


tides were released during the cheese-ripening process of young, medium-aged, and mature Gouda (Meisel et al., 1997). The sequences of several peptides with bioactivity, mainly VPP and IPP, have also been identified (Sieber et al., 2010). Pripp et al. (2006) showed a relationship between proteolysis activity and $\mathrm{ACE}$ activity in various cheeses, as indicated by an increase in ACE-inhibitory activity during cheese ripening.

Studies of WSE obtained from Mexican cheeses showed that Fresco cheese had the highest ACE inhibition and the lowest half-maximal inhibitory concentration $\left(\mathrm{IC}_{50}\right)$ values after $15 \mathrm{~d}$ of storage $(71.4 \%$ and 0.33 $\mathrm{mg} / \mathrm{mL}$, respectively; Santos-Espinosa et al., 2013). Crema de Chiapas cheese displayed the highest antioxidant activity at $15 \mathrm{~d}$ of storage when evaluated by ABTS method (Aguilar-Toalá et al., 2013). Likewise, Aguilar-Toalá et al. (2015) evaluated the antioxidant capacity of WSE fractions with a peptide size of $<3$ and 3 to $10 \mathrm{kDa}$ from Crema de Chiapas cheese from 3 different regions of Chiapas (north, center, and south) and from Mexico City. Results showed that antioxidant capacity increased significantly $(P<0.05)$ after $120 \mathrm{~d}$ of storage at $4^{\circ} \mathrm{C}$, and the fraction with $3-10 \mathrm{kDa}$ peptides had antioxidant capacity 2.5-fold higher than that of the fraction with $<3 \mathrm{kDa}$ peptides. Additionally, the antioxidant capacity of both fractions depended on the region, with the southern region having the highest antioxidant activity. In a separate study, antioxidant and ACE-inhibitory activities of acid-soluble $\mathrm{N}$ and NPN fractions obtained from Mexican artisanal Cotija cheese showed an increase in these activities with ripening time (Hernández-Galán et al., 2016).

\section{GABA}

$\gamma$-Aminobutyric acid, a 4-carbon nonprotein AA, is a metabolic product of plants and microorganisms produced by the decarboxylation of glutamic acid (Dhakal et al., 2012). Bacteria from the genera Lactobacillus and Lactococcus are reported to produce GABA from fermented foods, with Lactobacillus delbrueckii ssp. bulgaricus, Lactobacillus plantarum, and Lactobacillus paracasei being isolated from cheese (Siragusa et al., 2007). The production of GABA is affected by variables such as $\mathrm{pH}$, temperature, cultivation time, and additives in the culture medium. Glutamate decarboxylation occurs in LAB via reaction with the enzyme glutamic acid decarboxylase (GAD), resulting in the stoichiometric release of GABA and the consumption of a proton, thus increasing the alkalinity of the cytosol and the environment ( $\mathrm{Li}$ et al., 2010; Dhakal et al., 2012). pH is the principal regulator of GABA synthesis, and the biochemical characteristics of GAD differ between strains. For example, Lb. plantarum DSM19463 
synthesizes maximum amounts of GABA at pH 6.0 (Di Cagno et al., 2010), whereas Lb. paracasei NFRI 7415 produces maximum quantities at pH 5.0 (Kumar et al., 2000) and Lactobacillus brevis GABA 057 at $\mathrm{pH} 4.2$ (Yang et al., 2008). Temperature also affects the thermodynamic equilibrium of the reaction. For example, Lb. brevis NCL912 requires a high cell concentration and an appropriate culture temperature $\left(35^{\circ} \mathrm{C}\right.$; Li et al., 2010); whereas Lb. plantarum DSM19463 shows peak GABA production between 30 and $35^{\circ} \mathrm{C}$ (Di Cagno et al., 2010). In addition, Lb. plantarum DSM and $L b$. paracasei NFRI 7415 require 72 and $144 \mathrm{~h}$ of fermentation time, respectively, for major production of GABA (Higuchi et al., 1997; Di Cagno et al., 2010). The potential applications of GABA-producing microorganisms during the manufacture of foods such as cheese have been explored at length (Dhakal et al., 2012; Lacroix et al., 2013).

$\gamma$-Aminobutyric acid has several well-characterized physiological functions such as antihypertensive, immunomodulation, antidiuretic, and tranquilizing effects (Inoue et al., 2003; Hayakawa et al., 2004; Shimada et al., 2009; Wang et al., 2010). Additionally, some studies have shown that GABA can induce the secretion of insulin and therefore help prevent or manage diabetes (Adeghate and Ponery, 2002) and help treat alcoholism (Oh and Oh, 2003) and depression (Okada et al., 2000) by activating specific receptors and promoting lymphocyte proliferation. Intake of GABA can regulate sensations of pain and anxiety and lipid levels in serum (Miura et al., 2006). Another study linked GABA to an increase in the concentration of growth hormone in plasma and the rate of protein synthesis in the brain (Tujioka et al., 2009). In particular, one of the main benefits of GABA in cheese is its ability to induce hypotension in animals (Hayakawa et al., 2004) and humans (Inoue et al., 2003; Shimada et al., 2009).

The GABA content on 34 types of artisanal Spanish cheese was quantified by HPLC. Results showed GABA concentrations of up to $330 \mathrm{mg} / \mathrm{kg}$, which were not influenced by ripening stage or milk source (Diana et al., 2014). Furthermore, the concentration of GABA in Italian Pecorino Marchigiano and Pecorino Filiano cheeses ripened for 5 mo was 289 and $391 \mathrm{mg} / \mathrm{kg}$, respectively (Siragusa et al., 2007). Other studies have demonstrated the presence of GABA in varieties of Gouda, Cheddar, blue, and Edam cheeses, with GABA concentrations of $177,48,7.1$, and $4.2 \mu \mathrm{g} / \mathrm{g}$ of cheese, respectively (Nomura et al., 1998). These findings suggest that variations in total GABA depend on the type of cheese, type of ripening, and the quantity of protein in the raw material used, as well as the presence of native microbiota and the activity of proteolytic enzymes, which are the main factors responsible for AA release
(Yvon and Rijnen, 2001). Furthermore, the content of GABA in different types of Spanish cheese (mean 330 $\mathrm{mg} / \mathrm{kg}$ of cheese), given the average daily consumption $(21.8 \mathrm{~g} /$ person $)$, could mean that these products have a high physiological value for hypertension management (Diana et al., 2014).

Similarly, ripening conditions can promote an increase in GABA concentration due to glutamate released through casein proteolysis, low $\mathrm{pH}$, and anaerobiosis; this is also dependent on the type of LAB starter used. Lacroix et al. (2013) showed that 2 LAB starters, ULAAC-A and ULAAC-H, generated high amounts of GABA in Canadian cheeses.

Commercial cheeses from France were evaluated to identify GABA, which was detected in 4 of 9 cheeses. The highest concentration of GABA was found in Danish Havarti, with $324 \mathrm{mg} / 100 \mathrm{~g}$ of cheese, whereas Gouda cheese contained $129 \mathrm{mg} / 100 \mathrm{~g}$ of cheese. These results indicate that extensive ripening time and proteolysis of Danish Havarti promoted a greater concentration of free AA and a higher amount of glutamate, whereas, in Gouda and cheese slurry, the concentration of glutamate was minimal, indicating that total conversion to GABA had occurred (Lacroix et al., 2013).

\section{CLA}

In cheese, fat content varies between 20 and $35 \%$ of dry mass (Rippe, 2011). Of the fat content, approximately $66 \%$ is SFA, $30 \%$ is MUFA, and $4 \%$ is PUFA (López-Expósito et al., 2012). Fatty acids participate in various biological processes, serving as energy substrates and regulating cells, as well as influencing gene expression, PUFA bioavailability, and fat deposition. In addition, fatty acids may play a role in cancer prevention (Rioux and Legrand, 2007; Tvrzicka et al., 2011).

Conjugated linoleic acid refers to a group of isomers of linoleic acid (C18:2) with conjugated double bonds (MacDonald, 2000). The main isomers are cis-9,trans-11 CLA, trans-10,cis-12 CLA, and cis-9,cis-12 CLA, but the most biologically active isomer is cis-9, trans-11 (Lin et al., 1995; Ham et al., 2002; van Nieuwenhove et al., 2007).

Conjugated linoleic acid is naturally found in milk and is formed as a result of incomplete biohydrogenation of dietary fatty acids in the cow's rumen. Generally, dietary lipids are rapidly hydrolyzed in the rumen, and the resulting free UFA are subjected to biohydrogenation by microorganisms. Consequently, one part is absorbed by the rumen and another in the gastrointestinal tract, thereby incorporating CLA into mammary glands and milk fat (Kelly et al., 1998). Other factors involved in the subsequent formation of CLA in cheeses 
are the processing conditions, the raw milk composition, and prior fermentation time (Lin et al., 1995). Because CLA is formed in the rumen by microorganisms, it has been proposed that other microorganisms may also be capable of producing this fatty acid (Sieber et al., 2004). Therefore, LAB with the potential to produce CLA in culture medium and milk via linoleate isomerase activity have been evaluated (Jiang et al., 1998; Sieber et al., 2004) with the aim of incorporating adjunct cultures into milk to produce dairy products with a higher CLA content (Ham et al., 2002; van Nieuwenhove et al., 2007).

Nonetheless, CLA is naturally present in cheese, partly due to its natural content in milk and because LAB produce CLA via linoleate isomerase activity during milk fermentation; however, the linoleic acid content of milk is low, around 0.1 to $2.5 \mathrm{~g} / \mathrm{kg}$ of fat (Jenness, 1974). The identification of suitable lipid substrates would be necessary to achieve a greater bioconversion of CLA. The exact mechanism of CLA bioconversion remains largely unknown; it is thought that bacteria perform this conversion during detoxification to protect themselves from the antimicrobial activity of free fatty acids (Jiang et al., 1998). Lactic acid bacteria use hydratase, dehydrogenase, isomerase, and reductase enzymes to catalyze the biohydrogenation of fatty acids (Yang et al., 2014). The antioxidant activity of CLA has been proposed as a possible explanation of its anticarcinogenic effect and its role in the decrease of atherosclerosis (Ip et al., 1991). Additional beneficial effects of CLA include antiadipogenic, antidiabetogenic, and anti-inflammatory properties (Pariza et al., 2001; Ryder et al., 2001; Yang and Cook, 2003).

Another important fatty acid in cheese is phytanic acid $\left(\mathrm{C}_{20}\right)$, which is saturated with 4 methyl branches. This acid has a demonstrated ability to enhance glucose uptake in hepatocytes and may improve glucose homeostasis as well as protect against the development of MetS and type-2 diabetes (Hellgren, 2010).

\section{Organic Acids}

Autolysis of LAB in cheese allows intracellular enzymes involved in cheese ripening to reach their substrates more easily and then release antimicrobial substances such as organic acids, diacetyl, acetoin, hydrogen peroxide, and bacteriocins (Izco et al., 2002; Piraino et al., 2008). In this process, citric, orotic, pyruvic, lactic, uric, formic, acetic, propionic, butyric, and hippuric acids have been reportedly released in Ossalano cheese (Zeppa et al., 2001), as well as malic acid in Cheddar cheese (Murtaza et al., 2012).
These organic acids contribute toward cheese quality and flavor (Buffa et al., 2004). For example, propionic acid is key for the flavor development of Swiss-type cheese and is formed by Propionibacterium spp. through lactate metabolism (Califano and Bevilacqua, 2000). Organic acids act as antimicrobial agents capable of bacteriostatic and bactericidal activities, depending on the physiological status of the microorganism and the physicochemical characteristics of the external environment (Ricke, 2003). For instance, their acidity prevents the growth of spoilage-causing and pathogenic microorganisms, thereby improving the hygienic quality of cheese. The quantitative determination of organic acids is important for monitoring bacterial growth and sensory quality, as these acids contribute to the final flavor and aroma of cheese (Izco et al., 2002).

\section{Vitamins and Minerals}

Milk and dairy products contain vitamins and minerals in different quantities and represent a significant source of calcium. Semi-hard and hard cheeses contain 6 to $11 \mathrm{~g}$ of $\mathrm{Ca} / \mathrm{kg}$ of cheese. On the other hand, soft cheese has a lower Ca content due to the acidification of the vat milk used in its manufacture, yet the presence of $\mathrm{Ca}$ and vitamins varies similarly depending on the cheese variety (Eichholzer et al., 2005).

A greater concentration of fat-soluble vitamins, rather than water-soluble vitamins, is found in cheese because whey is removed during the manufacturing process. The main vitamins present in cheese are riboflavin, vitamin $\mathrm{B}_{12}$, niacin, folate, and vitamin A (López-Expósito et al., 2012). For instance, $50 \mathrm{~g}$ of Cheddar cheese can provide 28 and $32 \%$ of the recommended daily intake of vitamin A for men and women, respectively. This is especially important because vitamin A has various biological functions, such as stimulating the immune system, regulating gene expression, and sustaining lowlight vision (Russel, 2000).

In addition to $\mathrm{Ca}$, other important minerals in the cheese matrix are $\mathrm{Zn}, \mathrm{P}$, and $\mathrm{Mg}$. Calcium and $\mathrm{P}$ are found in greater proportion in cheese than in milk and are approximately 5 times more concentrated in soft cheeses, 8 times more concentrated in semi-hard cheeses, and up to 10 times more concentrated in hard cheeses (de la Fuente and Juarez, 2001). Calcium, along with vitamin $\mathrm{D}$, has the potential to safeguard against osteoporosis and encourage weight loss when combined with a low-calorie diet (Barba and Russo, 2006; Ash and Wilbey, 2010). One study reported that Ca encourages hypolipidemic mechanisms in the human body via inhibition of the absorption of fat and bile acids and 
increasing fecal fat excretion and Ca-induced conversion of cholesterol to bile acids (Tholstrup, 2006).

\section{HEALTH EFFECTS ASSOCIATED WITH CONSUMPTION OF RIPENED CHEESE}

Cheese is a product that is consumed widely around the world. The cheese-making process differs for each cheese type, the type of milk used, and different storage conditions. The metabolites discussed above are released in cheese and can be responsible for different health effects (Kumar et al., 2006). The use of animal and clinical studies indicates that consumption of cheese may contribute to reduced incidence of cardiovascular risk factors and other diseases that are mentioned below.

\section{Animal Models}

Studies using animal models have been conducted to evaluate the effect of the ripening process on enhancing the beneficial effects of cheese. In one study, different types of cheese ripened for $35 \mathrm{~d}$ were administered to diabetic $\mathrm{db} / \mathrm{db} \mathrm{C} 57 \mathrm{BL} / \mathrm{J}$ mice, and the effects were evaluated according to glucose tolerance, hepatic lipid content, and blood profiles $(P<0.05)$. The consumption of cheese ripened for $35 \mathrm{~d}$ significantly improved glucose tolerance without affecting insulin secretion, leading to a significant decrease in lipid peroxide markers (TBARS and NADPH-oxidase mRNA expression) in adipose tissues without affecting BW, food intake, or fat mass. In addition, the hepatic lipid content in mice significantly decreased (Geurts et al., 2012).

Cheese consumption has also been reported to reduce the risk of MetS in male Fischer-344 rats. The results of the study showed that serum adiponectin concentration was significantly higher in the cheese group than in the control group, and the concentrations of liver triglycerides and cholesterol were lower $(P=0.016$ and $P<0.001$, respectively) in the cheese group than in the control group 9 wk after initiation of the experiment. Thus, cheese intake lowered hepatic triglycerides and cholesterol in male rats fed a high-fat diet. The mechanisms of action could be related to the functional peptides produced during the ripening process, which may influence adiponectin concentration (Higurashi et al., 2016).

Cheddar cheese aged for 24 mo promoted the production of glycosylated proteins with a molecular weight of $23 \mathrm{kDa}$ derived from $\alpha_{\mathrm{S1}^{-}}$and $\beta$-casein. The glycosylated proteins showed resistance to in vitro gastrointestinal digestion and changed the relative abundances of fecal bacteria by increasing the Bacteroidetes:Firmicutes ratio and Bifidobacterium compared with the casein fermented control in obese mice. Furthermore, the metabolites released during fecal fermentation protected the HT-29 and fibroblast CCD-18Co cells from LPSinduced reactive oxygen species (Yuan et al., 2014).

Another important characteristic of cheese proteins and peptides is their effect on the inflammatory process and on inflammatory bowel disease. Several factors are involved in the development of the latter disease, such as genetic and environmental aspects, immunological malfunction, and intestinal microbiota (Sartor, 2006). Studies have demonstrated that the unavailability of the AA Thr, Cys, Ser, and Pro can limit mucin synthesis under conditions of inflammation and that supplementation with these AA increases mucin synthesis, resulting in positive histological changes in cases of colitis induced by dextran sulfate sodium in rats (Faure et al., 2006).

\section{Clinical Trials}

Growing evidence suggests that consumption of cheese may contribute to a reduced incidence of cardiovascular risk factors such as obesity, dyslipidemia, and type-2 diabetes (Table 2; Tholstrup et al., 2003, 2004; Sadeghi et al., 2014). Research has shown that the balance of gastrointestinal microbiota, in addition to microbiota functions, play an important role in maintaining health and preventing diseases (Marteau et al., 2002). In this respect, one study evaluated the effect of Camembert cheese intake compared with fermented milk intake on the composition and metabolism of human intestinal microbiota. The study evaluated feces to assess the microbiota of humans and rats in a culture medium via PCR-temporal temperature gradient gel electrophoresis. Intakes of cheese and fermented milk led to similar changes in bacterial metabolism, decreasing azoreductose activity and $\mathrm{NH}_{3}$ concentration and increasing mucolytic activities. Several specific changes were observed. For example, in microbiota-associated, Camembert pasteurized milk group (HMCp) rats, the proportion of ursodeoxycholic resulting from chenodeozycholic epimerization was higher. In microbiota-associated, fermented pasteurized milk group (HMfm) rats, $\alpha$ - and $\beta$-galactosidase were higher than in the other groups, and both azoreductases and nitrate reductases were lower. Overall, Camembert intake did not greatly modify the profile or major metabolic activities of the microbiota (Lay et al., 2004).

It is well established that the use of antimicrobial drugs for treating infections may have potentially adverse effects on normal intestinal microflora (Sullivan et al., 2001); namely, on the development of antimicrobial resistance in bacteria normally present as part of the 
INVITED REVIEW: BIOACTIVE COMPOUNDS IN CHEESE

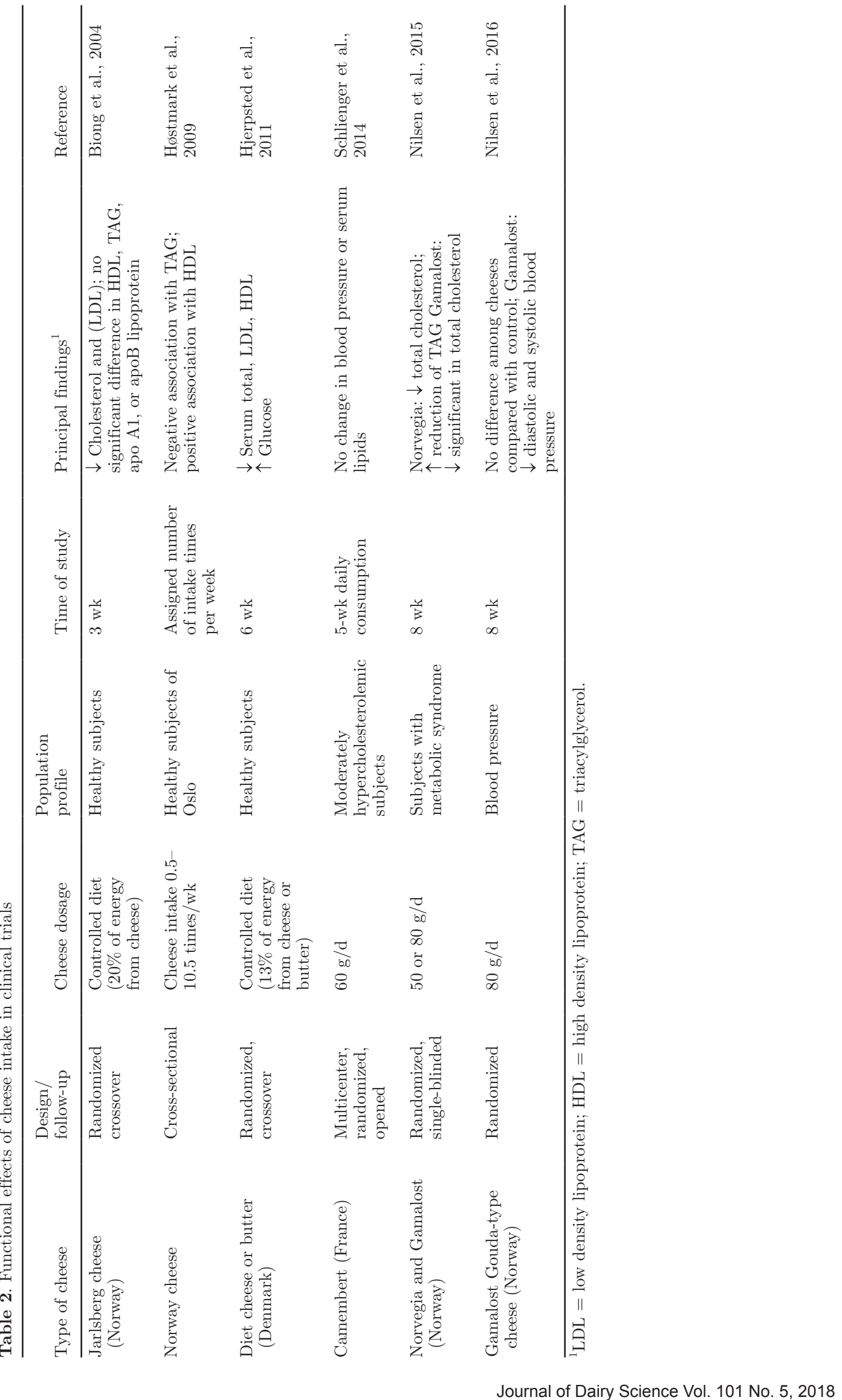


human microflora and on the overgrowth of pathogens already present in the intestine, such as yeasts and Clostridium difficile (Sullivan et al., 2001). A clinical pilot trial suggested that the intake of hard-cooked cheese during amoxicillin-clavulanic acid treatment lowered the occurrence of amoxicillin-resistant (Amox) strain in feces. This study consisted of 2 phases separated by $1 \mathrm{yr}$; during the first phase, the administration of amoxiclav increased the number of Escherichia coli and enterococci. The E. coli and enterococci were evaluated in feces samples and quantitatively by enterococci on Uriselect (Bio-Rad) and Slanetz and Bartley agar, respectively. The percentage of Amox E. coli increased from 0.5 to $32.95 \%$ at $\mathrm{d} 5$ and decreased progressively to baseline level $(0.5 \%)$ at $d 12$. Instead, the Amoxenterococci increased from 0.001 to $6.75 \%$ on $\mathrm{d} 5$ and remained stable at d $8(2.22 \%)$ and d $12(5.26 \%)$, decreasing to baseline level $(0.001 \%)$ at d 19 . In phase 2, the effect of amoxicillin-clavulanic on Amox E. coli increased from a baseline of 1 and $3 \%$ to $60 \%$ at d 5, 8 , 12 , and decreased to 3 and $8 \%$ until the end of the study. Six volunteers tested positive for Amox-enterococci. The pre-consumption (pre-antibiotic period) of cheese increased the presence of Amox E. coli $(P=0.0013)$ and in post-consumption (antibiotic posttreatment; $P$ $=0.006)$ but not during the consumption period $(P=$ $0.609)$. These results showed that consumption of hardcooked cheese can decrease the presence of the Amox enterococci in feces (Bertrand et al., 2007).

Hypercholesterolemia has been identified as a major risk for cardiovascular disease that is influenced by saturated fat intake and, as observed in human clinical trials, is associated with a high concentration of low-density lipoprotein (LDL) cholesterol (Gill et al., 2003). The atherogenic effect of dairy products with a high level of SFA has been poorly established in clinical studies (Schlienger et al., 2014). In fact, some cohort studies have reported that a high intake of full-fat dairy products or fermented milk may be associated with a lower risk of hypercholesterolemia (Bonthuis et al., 2010; Sonestedt et al., 2011). One study investigated the effect of 2 servings of Camembert cheese on serum lipids in moderately hypercholesterolemic individuals. After consuming 2 daily servings (60 g) of Camembert cheese over a 5-wk period, no changes were observed in blood pressure or serum lipids, suggesting that fermented cheese such as Camembert could be consumed daily without affecting serum lipids or blood pressure (Schlienger et al., 2014). In another study, a mixture of long-chain SFA in the diet increased plasma cholesterol and LDL cholesterol; thus, replacing SFA with PUFA could be a good approach to prevent coronary heart disease (Mensink et al., 2003, Jakobsen et al., 2009). Levels of myristic acid of up to $1.8 \%$ of total energy were associated with a decrease in LDL cholesterol in murine models, and an increase in high-density lipoprotein (HDL) cholesterol in both animal models and human trials (Tholstrup et al., 2003, 2004).

The bacteria involved in cheese ripening can potentially release metabolites, such as folic acid (Forssén et al., 2000). This could affect serum homocysteine levels (Appel et al., 2000), which have been identified as another risk factor for chronic heart disease when present at high levels (Wald et al., 2002). One randomized crossover trial was performed to further investigate the effect of aged cheese compared with butter on serum lipids, lipoproteins, homocysteine, and hemostatic levels, which are risk factors for chronic heart disease. Subjects consumed 1 of 3 diets for 3 wk: cheese, butter + casein, and butter + egg white. Cholesterol levels were significantly lower in individuals fed the cheese diet and in those fed the butter + casein diet (difference between means of cheese and butter + casein diet: $-0.27 \mathrm{mmol} / \mathrm{L} ; P=0.03$ ), although this latter difference was not significant. No significant differences $(-0.22 \mathrm{mmol} / \mathrm{L}, P=0.06)$ were found for HDL cholesterol, triacylglycerols, hemostatic, homocysteine, and apo A-1 and apo B lipoprotein levels among the 3 diets. These results show that a diet with heavy cheese consumption may induce lower cholesterol levels than a diet with high butter consumption (Biong et al., 2004).

An additional study evaluated the effect of an experimental Cheddar cheese enriched with $16 \mathrm{mg}$ of GABA on blood pressure of 23 men (20-65 yr of age) with slightly elevated blood pressure, and considering a placebo-controlled and a double-blind study group. For $12 \mathrm{wk}$, subjects consumed daily $50 \mathrm{~g}$ of the GABAenriched cheese. Results demonstrated that blood pressure $(P=0.034)$ and systolic blood pressure $(P=0.048)$ decreased as a function of intervention time; however, no time by treatment interaction was observed. At the end of the experimental period, blood pressure decreased by $3.5 \mathrm{mmHg}$ and systolic blood pressure by 5.5 $\mathrm{mmHg}$. Furthermore, no significant change in diastolic blood pressure was observed following the consumption of Cheddar cheese with or without GABA enrichment (Pouliot-Mathieu et al., 2013).

Other studies have proven that consumption of milk and dairy products is associated with a decreased prevalence of MetS, a prediabetic condition characterized by a waist circumference $>80 \mathrm{~cm}$ for women and $>94 \mathrm{~cm}$ for men. Furthermore, the population sectors that present with MetS have a higher risk of developing coronary heart disease. Risk factors include high triglyceride, HDL, and cholesterol levels, high fasting blood glucose, and high systolic or diastolic blood pressure (IDF, 2009). The frequency of cheese intake was inversely related to serum triglycerides and posi- 
tively related to serum HDL cholesterol concentration (Elwood et al., 2007; Høstmark et al., 2009). Another study examined the association between the frequency of self-reported cheese intake and an index for estimating the risk of diabetes and cardiovascular disease. The study showed an inverse association between frequency of cheese intake and MetS risk, except in older men (75-76 yr). Furthermore, individuals with a greater number of MetS risk factors consumed cheese at a lower frequency, whereas cheese intake was significantly $(P=$ 0.005 for men and $P=0.001$ for women) and inversely related to MetS risk factors, and cheese intake showed an inverse association with body mass index $(P=0.02)$ (Høstmark and Tomten, 2011). Although other studies have found a positive relationship between cheese consumption and BW, several factors need to be considered, such as study design, the sampled population (age, sex, ethnicity), and lifestyle factors (Beydoun et al., 2008).

\section{CONCLUSIONS}

Cheese is widely consumed around the world and plays an important role in human nutrition. In recent years, dairy products (cheese in particular) have received negative press over their potential adverse effects on health; nevertheless, consumption of dairy products has also been associated with several health benefits. For example, cheese intake has demonstrated potential in lowering blood pressure and decreasing cardiovascular risk factors (obesity, dyslipidemia, and type 2 diabetes), although the studies are not entirely conclusive. The composition of cheese represents a good matrix for the release of bioactive compounds, which increase during the cheese ripening process by the action of LAB. Several studies have been directed at peptides; however, the presence of compounds such as GABA and CLA are important metabolites also released by $\mathrm{LAB}$, which have shown potential in disease prevention. Other important compounds such as exopolysaccharides, which enhance the rheological properties of cheese, can have antioxidant, antimicrobial, and immunological properties. The identification of cheese bioactive compounds is of primary importance, as is their characterization via metabolomics, separation, and detection techniques. Further in vitro and in vivo studies are necessary to document the health benefits and bioactive effects derived from consumption of fresh and ripened cheese.

\section{ACKNOWLEDGMENTS}

The authors thank the National Council for Science and Technology (CONACyT) of Mexico for the gradu- ate scholarships provided to L. Santiago-López and J. E. Aguilar-Toalá. This study was supported by the Mexican Council of Science and Technology (CONACYT; México City, Mexico) research project 240338.

\section{REFERENCES}

Abadía-García, L., A. Cardador, S. T. Martin del Campo, S. M. Arvízu, E. Castaño-Tostado, C. Regalado-González, B. GarcíaAlmendarez, and S. L. Amaya-Llano. 2013. Influence of probiotic strains added to Cottage cheese on generation of potentially antioxidant peptides, anti-listerial activity, and survival of probiotic microorganisms in simulated gastrointestinal conditions. Int. Dairy J. 3:191-197.

Adeghate, E., and A. S. Ponery. 2002. GABA in the endocrine pancreas: Cellular localization and function in normal and diabetic rats. Tissue Cell 34:1-6.

Aguilar-Toalá, J. E., A. F. González-Córdova, A. Hernández-Mendoza, M. J. Torres-Llanez, and B. Vallejo-Cordoba. 2013.Antioxidant activity of bioactive peptides and polyphenols isolated from Mexican Artisanal Cheeses. Abstract number 072-04 in IFT Annual Meeting and Expo, Chicago, IL. Institute of Food Technologists, Chicago, IL.

Aguilar-Toalá, J. E., B. Vallejo-Cordoba, A. Hernández-Mendoza, and A. F. González-Córdova. 2015. Antioxidant capacity of water soluble extracts obtained from Queso Crema de Chiapas, an Artisanal Mexican Cheese. Abstract number 023 in IFT Annual Meeting and Expo, Chicago, IL. Institute of Food Technologists, Chicago, IL.

Albenzio, M., M. R. Corbo, S. U. Rehman, P. F. Fox, M. De Angelis, A. Corsetti, A. Sevi, and M. Gobbetti. 2001. Microbiological and biochemical characteristics of Canestrato Pugliese cheese made from raw milk, or by heating the curd in hot whey. Int. J. Food Microbiol. 67:35-48.

Appel, L. J., E. R. I. I. I. Miller, S. H. Jee, R. Stolzenberg-Solomon, P. H. Lin, T. Erlinger, M. R. Nadeau, and J. Selhub. 2000. Effect of dietary patterns on serum homocysteine: Results of a randomized, controlled feeding study. Circulation 102:852-857.

Ash, A., and A. Wilbey. 2010. The nutritional significance of cheese in the UK diet. Int. J. Dairy Technol. 63:305-319.

Barba, G., and P. Russo. 2006. Dairy foods, dietary calcium and obesity: A short review of evidence. Nutr. Metab. Cardiovasc. Dis. 16:445-451.

Beermann, C., and J. Hartung. 2013. Physiological properties of milk ingredients released by fermentation. Food Funct. 4:185-199.

Bernabucci, U., E. Catalani, L. Basirico, P. Morera, and A. Nardone. 2014. In vitro ACE-inhibitory activity and in vivo antihypertensive effects of water-soluble extract by Parmigiano Reggiano and Grana Padano cheeses. Int. Dairy J. 37:16-19.

Bertrand, X., V. Dufour, L. Millon, E. Beuvier, H. Gbaguidi-Haore, R. Piarroux, D. A. Vuitton, and D. Talon. 2007. Effect of cheese consumption on antimicrobial resistance in the intestinal microflora induced by a short course of amoxicillin-clavulanic acid. J. Appl. Microbiol. 102:1052-1059.

Beydoun, M. A., T. L. Gary, B. H. Caballero, R. S. Lawrence, L. J. Cheskin, and Y. Wang. 2008. Ethnic differences in dairy and related nutrient consumption among US adults and their association with obesity, central obesity, and the metabolic syndrome. Am. J. Clin. Nutr. 87:1914-1925.

Biong, A. S., H. Müller, I. Seljeflot, M. B. Veirod, and J. I. Pedersen. 2004. A comparison of the effects of cheese and butter on serum lipids, haemostatic variables and homocysteine. Br. J. Nutr. 92:791-797.

Bonthuis, M., M. C. B. Hughes, T. I. Ibiebele, A. C. Green, and J. C. van der Pols. 2010. Dairy consumption and patterns of mortality of Australian adults. Eur. J. Clin. Nutr. 64:569-577.

Bottesini, C., S. Paolella, F. Lambertini, G. Galavera, T. Tedeschi, A. Dossena, R. Marchelli, and S. Sforza. 2013. Antioxidant capacity of water soluble extracts from Parmigiano-Reggiano cheese. Int. J. Food Sci. Nutr. 64:953-958. 
Buffa, M., B. Guamis, J. Saldo, and A. J. Trujillo. 2004. Changes in organic acids during ripening of cheeses made from raw, pasteurized or high-pressure-treated goats milk. Lebensm. Wiss. Technol. $37: 247-253$

Califano, A. N., and A. E. Bevilacqua. 2000. Multivariate anaysis of the organic acids content of Gouda type cheese during ripening. J. Food Compos. Anal. 13:949-960.

Casey, M. G., J. P. Häni, J. Gruskovnjak, W. Schaeren, and D. Wechsler. 2006. Characterisation of the non-starter lactic acid bacteria (NSLAB) of Gruyere PDO cheese. Lait 86:407-414.

Chavan, R. S., S. R. Chavan, C. D. Khedkar, and A. H. Jana. 2011. UHT milk processing and effect of plasmin activity on shelf life: A review. Compr. Rev. Food Sci. Food Saf. 10:251-268.

Claeys, W. L., S. Cardoen, G. Daube, J. De Block, K. Dewettinck, K. Dierick, L. Zutter, A. Huyghebaert, H. Imberechst, P. Thiange, Y. Vandenplas, and L. Herman. 2012. Raw or heated cow milk consumption: review of risks and benefits. Food Control 31:251-262.

Cruz, A. G., J. A. F. Faria, M. A. R. Pollonio, H. M. A. Bolini, R. M. S. Celeghini, D. Granato, and N. P. Shah. 2011. Cheese with reduced sodium content: effects on functionality, public health benefits and sensory properties. Trends Food Sci. Technol. 22:276-291.

Cuchillo-Hilario, M., P. G. Delgadillo, N. Wrage, and R. F. Perez-Gil 2010. Feeding goats on scrubbly Mexican rangeland and pasteurization: Influence on milk and artisan cheese quality. Trop. Anim. Health Prod. 42:1127-1134

de la Fuente, M. A., and M. Juárez. 2001. Los quesos: Una fuente de nutrientes. Aliment. Nutr. Salud 8:75-83.

Dhakal, R., V. K. Bajpai, and K.-H. Baek. 2012. Production of GABA ( $\gamma$-aminobutyric acid) by microorganisms: A review. Braz. J. Microbiol. 43:1230-1241.

Di Cagno, R., F. Mazzacane, C. G. Rizzello, M. D. E. Angelis, G. Giuliani, M. Meloni, B. D. E. Servi, and G. Marco. 2010. Synthesis of $\gamma$-aminobutyric acid (GABA) by Lactobacillus plantarum DSM19463: Functional grape must beverage and dermatological applications. Appl. Microbiol. Biotechnol. 86:731-741.

Diana, M., M. Rafecas, C. Arco, and J. Quilez. 2014. Free amino acid profile of Spanish artisanal cheeses: Importance of gamma-aminobutyric acid (GABA) and ornithine content. J. Food Compos. Anal. 35:94-100.

Eichholzer, M., E. Camenzid, A. Matzke, R. Amado, P. E. Ballmer, M Beer, R. Darioli, K. Hasler, J. Lüthy, U. Moser, R. Sieber, and C. Trabichet. 2005. Trabichet Fünfter Schweizerischer Ernährungsbericht, Bundesamt für Gesundheit, Bern, Switzerland.

Elias, R. J., S. S. Kellerby, and E. A. Decker. 2008. Antioxidant activity of proteins and peptides. Crit. Rev. Food Sci. Nutr. 48:430-441.

Elwood, P. C., J. E. Pickering, and A. M. Fehily. 2007. Milk and dairy consumption, diabetes and the metabolic syndrome: The Caerphilly prospective study. J. Epidemiol. Community Health 61:695-698.

Faure, M., C. Mettraux, D. Moennoz, J. P. Godin, J. Vuichoud, F. Rochat, D. Breuille, C. Obled, and I. Corthesy-Thelaz. 2006. Specific amino acids increase mucin synthesis and microbiota in dextran sulfate sodium-treated rats. J. Nutr. 136:1558-1564.

Fitzgerald, R., and B. A. Murray. 2006. Bioactive peptides and lactic fermentations. Int. J. Dairy Technol. 59:118-125.

Forssén, K. M., M. I. Jägerstad, K. Wigertz, and C. M. Witthöft. 2000. Folates and dairy products: A critical update. J. Am. Coll. Nutr. 19:100S-110S.

Gagnaire, V., D. Mollé, M. Herrouin, and J. Léonil. 2001. Peptides identified during Emmental cheese ripening: origin and proteolytic systems involved. J. Agric. Food Chem. 49:4402-4413.

Geurts, L., A. Everard, P. Ruyet, N. M. Delzenne, and P. D. Cani 2012. Ripened dairy products differentially affect hepatic lipid content and adipose tissue oxidative stress markers in obese and type 2 diabetic mice. J. Agric. Food Chem. 60:2063-2068.

Gill, J. M., J. C. Brown, M. J. Caslake, D. M. Wright, J. Cooney, D. Bedford, D. A. Hughes, J. C. Stanley, and C. J. Packard. 2003. Effects of dietary monounsaturated fatty acids on lipoprotein concentrations, compositions, and subfraction distributions and on LDL apolipoprotein B kinetics: Dose-dependent effects on LDL. Am. J. Clin. Nutr. 78:47-56.
Gómez-Ruiz, J. A., G. Taborda, L. Amigo, I. Recio, and M. Ramos. 2006. Identification of ACE-inhibitory peptides in different Spanish cheeses by tandem mass spectrometry. Eur. Food Res. Technol. 223:595-601.

González, L., N. Sacristán, R. Arenas, J. M. Fresno, and M. Eugenia Tornadijo. 2010. Enzymatic activity of lactic acid bacteria (with antimicrobial properties) isolated from a traditional Spanish cheese. Food Microbiol. 27:592-597.

Grattepanche, F., S. Miescher-Schwenninger, L. Meile, and C. Lacroix. 2008. Recent developments in cheese cultures with protective and probiotic functionalities. Dairy Sci. Technol. 88:421-444.

Gupta, A., B. Mann, R. Kumar, and R. B. Sangwan. 2009. Antioxidant activity of Cheddar cheeses at different stages of ripening. Int. J. Dairy Technol. 62:339-347. https://doi.org/10.1111/j.1471 $-0307.2009 .00509 . x$

Ham, J. S., Y. M. In, S. G. Jeong, J. G. Kim, E. H. Lee, H. S. Kim, S. K. Yoon, and B. H. Lee. 2002. Screening of conjugated linoleic acid producing lactic acid bacteria from fecal samples of healthy babies. Asian-australas. J. Anim. Sci. 15:1031-1035.

Hartmann, R. and H. Meisel. 2007. Food-derived peptides with biological activity: From research to food applications. Curr. Opin. Biotechnol. 18:163-169.

Hayakawa, K., M. Kimura, K. Kasaha, K. Matsumoto, H. Sansawa, and Y. Yamori. 2004. Effect of g-aminobutiric acid-enriched dairy product on the blood pressure of spontaneously hypertensive and normotensive Wistar-Kyoto rats. Br. J. Nutr. 92:411-417.

Hellgren, L. I. 2010. Phytanic acid-An overlooked bioactive fatty acid in dairy fat? Ann. N. Y. Acad. Sci. 1190:42-49.

Hernandez-Galán, L., A. Cardador-Martínez, M. López-del-Castillo, D. Picque, H. E. Spinnler, and S. T. Martin del Campo. 2017. Antioxidant and angiotensin-converting enzyme inhibitory activity in fresh goat cheese prepared without starter culture: A preliminary study. CYTA J. Food 15:49-57.

Hernández-Galán, L., A. Cardador-Martínez, D. Picque, H. E. Spinnler, M. López-del-Castillo Lozano, and S. T. Martín del Campo. 2016. Angiotensin converting enzyme inhibitors and antioxidant peptides release during ripening of Mexican Cotija hard cheese. J. Food Res. 5:85-91.

Hernández-Ledesma, B., M. del Mar Contreras, and I. Recio. 2011. Antihypertensive peptides: Production, bioavailability and incorporation into foods. Adv. Colloid Interface Sci. 165:23-35.

Higuchi, T., H. Hayashi, and K. Abe. 1997. Exchange of glutamate and g-aminobutyrate in a Lactobacillus strain. J. Bacteriol. 179:33623364 .

Higurashi, S., A. Ogawa, T. Y. Nara, K. Kato, and Y. Kodooka. 2016. Cheese consumption prevents fat accumulation in the liver and improve serum lipid parameters in rats fed a high-fat diet. Dairy Sci. Technol. 96:539-549.

Hjerpsted, J., E. Leedo, and T. Tholstrup. 2011. Cheese intake in large amounts lowers LDL-cholesterol concentrations compared with butter intake of equal fat content. Am. J. Clin. Nutr. 94:1479-1484.

Høstmark, A. T., A. Haug, S. E. Tomten, D. S. Thelle, and A. Mosdol 2009. Serum HDL cholesterol was positively associated with cheese intake in the Oslo Health Study. J. Food Lipids 16:89-102.

Høstmark, A. T., and S. Tomten. 2011. The Oslo Health Study: Cheese intake was negatively associated with the metabolic syndrome. J. Am. Coll. Nutr. 30:182-190.

Inoue, K., T. Shirai, H. Ochiai, M. Kasaom, K. Hayakawa, M. Kimura, and H. Sansawa. 2003. Blood-pressure-lowering effect of a novel fermented milk containing gamma-aminobutyric acid (GABA) in mild hypertensives. Eur. J. Clin. Nutr. 57:490-495.

IDF (International Diabetes Federation. 2009. The IDF Consensus Worldwide Definition of the Metabolic Syndrome. Accessed Mar. 5, 2010. http://www.idf.org/webdata/docs/MetS_def_update2006 .pdf.

Ip, C., S. F. Chin, J. A. Scimeca, and M. W. Pariza. 1991. Mammary cancer prevention by conjugated dienoic derivate of linoleic acid. Cancer Res. 15:6118-6124.

Irlinger, F., and J. Mounier. 2009. Microbial interactions in cheese: Implications for cheese quality and safety. Curr. Opin. Biotechnol. $20: 142-148$. 
Izco, J. M., M. Tormo, and R. Jiménez-Flores. 2002. Rapid simultaneous determination of organic acids, free amino acids, and lactose in cheese by capillary electrophoresis. J. Dairy Sci. 85:2122-2129.

Jakobsen, M. U., E. J. O'Reilly, B. L. Heitmann, M. A. Pereira, K. Bälter, G. E. Fraser, U. Goldbourt, G. Hallmans, P. Knekt, S. Liu, P. Pietinen, D. Spiegelman, J. Stevens, J. Virtamo, W. C. Willett, and A. Ascherio. 2009. Major types of dietary fat and risk of coronary heart disease: A pooled analysis of 11 cohort studies. Am. J. Clin. Nutr. 89:1425-1432.

Jenness, R. 1974. Biosynthesis and composition of milk. J. Invest. Dermatol. 63:109-118.

Jiang, J., L. Bjorck, and R. Fonden. 1998. Production of conjugated linoleic acid by dairy starter cultures. J. Appl. Microbiol. 85:95102.

Kelly, M. L., J. R. Berry, D. A. Dwyer, J. M. Griinari, P. Y. Chouinard, M. E. Van Amburgh, and D. E. Bauman. 1998. Dietary fatty acid sources affect conjugated linoleic acid concentrations in milk from lactating dairy cows. J. Nutr. 128:881-885.

Kitts, D. D., and K. Weiler. 2003. Bioactive proteins and peptides from food sources. Applications of bioprocesses used in isolation and recovery. Curr. Pharm. Des. 9:1309-1323.

Kumar, S., N. S. Punekar, V. Satyanarayan, and K. V. Venkatesh. 2000. Metabolic fate of glutamate and evaluation of flux through the 4-aminobutyrate (GABA) shunt in Aspergillus niger. Biotechnol. Bioeng. 67:575-584.

Kumar, V. V., V. Sharma, and B. S. Bector. 2006. Effect of ripening on total conjugated linoleic acid and its isomers in buffalo Cheddar cheese. Int. J. Dairy Technol. 59:257-260.

Lacroix, N., D. St-Gelais, C. P. Champagne, and J. C. Vuillemard. 2013. Gamma-aminobutyric acid-producing abilities of lactococcal strains isolated from old-style cheese starters. Dairy Sci. Technol. 93:315-327.

Lay, C., M. Sutren, P. Lepercq, C. Juste, L. Rigottier-Gois, E. Lhoste, R. Lemee, P. L. Ruyet, J. Doré, and C. Andrieux. 2004. Influence of Camembert consumption on the composition and metabolism of intestinal microbiota: A study in human microbiota-associated rats. Br. J. Nutr. 92:429-438.

Leroy, F., and L. De Vuyst. 2004. Lactic acid bacteria as functional starter cultures for the food fermentation industry. Trends Food Sci. Technol. 15:67-78

Li, H., T. Qiu, G. Huang, and Y. Cao. 2010. Production of gammaaminobutyric acid by Lactobacillus brevis NCL912 using fed batch fermentation. Microb. Cell Fact. 12:85.

Lignitto, L., V. Cavatorta, S. Balzan, G. Gabai, G. Galaverna, E. Novelli, S. Sforza, and S. Segato. 2010. Angiotensin-converting enzyme inhibitory activity of water-soluble extracts of Asiago d'allevo cheese. Int. Dairy J. 20:11-17.

Lin, H., T. D. Boylston, M. J. Chang, L. O. Luedecke, and T. D. Shultz. 1995. Survey of the conjugated linoleic acid contents of dairy products. J. Dairy Sci. 78:2358-2365.

Liu, M., J. R. Bayjanov, B. Renckens, A. Nauta, and R. J. Siezen. 2010. The proteolytic system of lactic acid bacteria revisited: A genomic comparison. BMC Genomics 11:36.

López-Expósito, I., L. Amigo, and I. Recio. 2012. A mini-review on health nutritional aspects of cheese with a focus on bioactive peptides. Dairy Sci. Technol. 92:419-438.

Mao, X. Y., J. R. Ni, W. L. Sun, P. P. Hao, and L. Fan. 2007. Value-added utilization of yak milk casein for the production of angiotensin-I-converting enzyme inhibitory peptides. Food Chem. 103:1282-1287.

Marteau, P., P. Seksik, and R. Jian. 2002. Probiotics and intestinal health effects: A clinical perspective. Br. J. Nutr. 88:S51-S57.

MacDonald, H. B. 2000. Conjugated linoleic acid and disease prevention: A review of current knowledge. J. Am. Coll. Nutr. 19111S$19118 \mathrm{~S}$.

McSweeney, P. L. H. 2004. Biochemistry of cheese ripening. Int. J. Dairy Technol. 57:127-144.

Meira, S. M. M., D. J. Daroit, V. E. Helfer, A. P. F. Correa, J. Segalin, S. Carro, and A. Brandelli. 2012. Bioactive peptides in water-soluble extracts of ovine cheeses from Southern Brazil and Uruguay. Food Res. Int. 48:322-329.
Meisel, H., A. Goepfert, and S. Günther. 1997. ACE-inhibitory activities in milk products. Milchwissenschaft 52:307-311.

Mensink, R. P., P. L. Zock, A. D. Kester, and M. B. Katan. 2003. Effects of dietary fatty acids and carbohydrates on the ratio of serum total to HDL cholesterol and on serum lipids and apolipoproteins: a meta-analysis of 60 controlled trials. Am. J. Clin. Nutr. $77: 1146-1155$.

Miura, D., Y. Ito, A. Mizukuchi, M. Kise, H. Aoto, and K. Yagasaki. 2006. Hypercholesterolemic action of pre-germinated brown rice in hepatoma-bearing rats. Life Sci. 79:259-264.

Moatsou, G., C. Bakopanos, D. Katharios, G. Katsaros, I. Kandarakis, P. Taoukis, and I. Politis. 2008. Effect of high-pressure treatment at various temperatures on indigenous proteolytic enzymes and whey protein denaturation. J. Dairy Res. 75:262-269.

Murtaza, M. A., S. U. Rehman, F. M. Anjum, N. Huma, O. M. Tarar, and G. Mueen-Ud-Din. 2012. Organic acid contents of buffalo milk cheddar cheese as influenced by accelerated ripening and sodium salt. J. Food Biochem. 36:99-106.

Nilsen, R., A. T. Hǿstmark, A. Haug, and S. Skeie. 2015. Effect of a high intake of cheese on cholesterol and metabolic syndrome: results of a randomized trial. Food Nutr. Res. 59:27651.

Nilsen, R., A. H. Pripp, A. T. Hǿstmark, A. Haug, and S. Skeie. 2016. Effect of a cheese rich in angiotensin-converting enzyme-inhibiting peptides (Gamalost) and a Gouda-type cheese on blood pressure: results of a randomized trial. Food Nutr. Res. 60:32017. https:// doi.org/10.3402/fnr.v60.32017.

Nomura, M., H. Kimoto, Y. Someya, S. Furukawa, and I. Suzuki. 1998. Production of $\gamma$-aminobutyric acid by cheese starters during cheese ripening. J. Dairy Sci. 81:1486-1491.

Oh, S. H., and C. H. Oh. 2003. Brown rice extracts with enhanced levels of GABA stimulate immune cells. Food Sci. Biotechnol. $12: 248-252$.

Okada, T., T. Sugishita, T. Murakami, H. Murai, T. Saikusa, T. Horino, A. Onoda, O. Kajimoto, R. Takahashi, and T. Takahashi. 2000. Effect of the defatted rice germ enriched with GABA for sleeplessness, depression, autonomic disorder by oral administration. Nippon Shokuhin Kagaku Kogaku Kaishi 47:596-603.

Okamoto, A., H. Hanagata, E. Matsumoto, Y. Kawamura, Y. Koizumi, and F. Yanagida. 1995. Angiotensin-converting enzyme inhibitory activities of various fermented foods. Biosci. Biotechnol. Biochem. 59:1147-1149.

Ong, L., A. Henriksson, and N. P. Shah. 2007. Angiotensin converting enzyme-inhibitory activity in Cheddar cheeses made with the addition of probiotic Lactobacillus casei sp. Lait 87:149-165.

Ong, L., and N. P. Shah. 2008. Influence of probiotic Lactobacillus acidophilus and Lactobacillus helveticus on proteolysis, organic acid profiles, and ACE-inhibitory activity of cheddar cheeses ripened at 4, 8, and $12{ }^{\circ} \mathrm{C}$. J. Food Sci. 73:111-120.

Pariza, M. W., Y. Park, and M. E. Cook. 2001. The biologically active isomers of conjugated linoleic acid. Prog. Lipid Res. 40:283-298.

Paul, M., J. D. Brewster, D. L. Van Hekken, and P. M. Tomasula. 2012. Measuring the antioxidative activities of Queso Fresco after post-packaging high-pressure processing. Adv. Biosci. Biotechnol. 3:297-303.

Pepe, G., E. Sommella, G. Ventre, M. C. Scala, S. Adesso, C. Ostacolo, S. Marzocco, E. Novellino, and P. Campiglia. 2016. Antioxidant peptides released from gastrointestinal digestion of "Stracchino" soft cheese: characterization, in vitro intestinal protection and bioavailability. J. Funct. Foods 26:494-505.

Phelan, M., A. Aherne, R. J. FitzGerald, and N. M. O'Brien. 2009. Casein-derived bioactive peptides: Biological effects, industrial uses, safety aspects and regulatory status. Int. Dairy J. 19:643-654.

Piraino, P., T. Zotta, A. Ricciardi, P. L. H. McSweeney, and E. Parente. 2008. Acid production, proteolysis, autolytic and inhibitory properties of lactic acid bacteria isolated form pasta filata cheeses: a multivariate screening study. Int. Dairy J. 18:81-92.

Pouliot-Mathieu, K., C. Gardner-Fortier, S. Lemieux, S. St-Gelais, C. P. Champagne, and J. C. Vuillemard. 2013. Effect of cheese containing gamma-aminobutyric acid-producing lactic acid bacteria on blood pressure in men. PharmaNutrition 1:141-148. 
Pripp, A. H., R. Sorensen, L. Stepaniak, and T. Sorhaug. 2006. Relationship between proteolysis and angiotensin-I-converting enzyme inhibition in different cheeses. Lebensm. Wiss. Technol. 39:677683.

Pritchard, S. R., M. Phillips, and K. Kailasapathy. 2010. Identification of bioactive peptides in commercial Cheddar cheese. Food Res. Int. 43:1545-1548.

Ricke, S. C. 2003. Perspectives on the use of organic acids and short chain fatty acids as antimicrobial. Poult. Sci. 82:632-639.

Rioux, V., and P. Legrand. 2007. Saturated fatty acids: Simple molecular structures with complex cellular functions. Curr. Opin. Clin. Nutr. Metab. Care 10:752-758.

Rippe, J. M. 2011. Encyclopedia of Lifestyle Medicine and Health. SAGE Publications, Thousand Oaks, CA.

Rizzello, C. G., I. Losito, M. Gobbetti, T. Carbonara, M. D. de Bari, and P. G. Zambonin. 2005. Antibacterial activities of peptides from the water-soluble extracts of Italian cheese varieties. J. Dairy Sci. 88:2348-2360

Russell, R. M. 2000. The vitamin A spectrum: From deficiency to toxicity. Am. J. Clin. Nutr. 71:878-884.

Ryahanen, E., A. Pihlanto-Leppala, and E. Pahkala. 2001. A new type of ripened, low-fat cheese with bioactive peptides. Int. Dairy J. 11:441-447.

Ryder, J. W., C. P. Portocarrero, X. M. Song, L. Cui, M. Yu, T Combatsiaris, D. Galuska, D. E. Bauman, D. M. Barbano, M. J. Charron, J. R. Zierath, and K. L. Houseknecht. 2001. Isomer-specific antidiabetic properties of conjugated linoleic acid. Improved glucose tolerance, skeletal muscle insulin action, and UCP-2 gene expression. Diabetes 50:1149-1157.

Sadeghi, M., H. Khosravi-Boroujeni, N. Sarrafzadegan, S. Asgary, H. Roohafza, M. Gharipour, F. Sajjadi, S. Khalesi, and M. RafieianKopaei. 2014. Cheese consumption in relation to cardiovascular risk factors among Iranian adults-IHHP study. Nutr. Res. Pract. $8: 336-341$.

Saito, T., T. Nakamura, H. Kitazawa, Y. Kawai, and T. Itoh. 2000. Isolation and structural analysis of antihypertensive peptides that exist naturally in Gouda cheese. J. Dairy Sci. 83:1434-1440.

Saldo, J., A. Fernández, E. Sendra, P. Butz, B. Tauscher, and B. Guamis. 2003. High pressure treatment decelerates the lipolysis in a caprine cheese. Food Res. Int. 36:1061-1068.

Samaranayaka, A. G. P., and E. C. Y. Li-Chan. 2011. Food-derived peptidic antioxidants: A review of their production, assessment, and potential applications. J. Funct. Foods 3:229-254.

Santos-Espinosa, A., A. F. González-Córdova, A. Hernández-Mendoza, M. C. Estrada-Montoya, and B. Vallejo-Cordoba. Angiotensinconverting enzyme inhibitory activity of Mexican Artisanal Cheeses. In: Abstract number 072-05 in IFT Annual Meeting and Expo, Chicago, IL. Institute of Food Technologists, Chicago, IL; 2013.

Sartor, R. B. 2006. Mechanisms of disease: Pathogenesis of Crohn's disease and ulcerative colitis. Nat. Clin. Pract. Gastroenterol. Hepatol. 3:390-407.

Savijoki, K., H. Ingmer, and P. Varmanen. 2006. Proteolytic systems of lactic acid bacteria. Appl. Microbiol. Biotechnol. 71:394-406.

Schlienger, J.-L., F. Paillard, J. M. Lecerf, M. Romon, C. Bonhomme, B. Schmit, Y. Donazzolo, C. Defoort, C. Mallmann, P. L. Ruyet, and J. L. Bresson. 2014. Effect on blood lipids of two daily servings of Camembert cheese. An intervention trial in mildly hypercholesterolemic subjects. Int. J. Food Sci. Nutr. 65:1013-1018.

Settanni, L., and G. Moschetti. 2010. Non-starter lactic acid bacteria used to improve cheese quality and provide health benefits. Food Microbiol. 27:691-697.

Shimada, M., T. Hasegawa, C. Nishimura, H. Kan, T. Nakamura, and T. Matsubayashi. 2009. Anti-hypertensive effect of gammaaminobutyric acid (GABA)-rich Chlorella on high-normal blood pressure and borderline hypertension in placebo-controlled double blind study. Clin. Exp. Hypertens. 31:342-354

Sieber, R., U. Butikofer, C. Egger, R. Portmann, B. Walther, and D. Wechsler. 2010. ACE-inhibitory activity and ACE-inhibiting peptides in different cheese varieties. Dairy Sci. Technol. 90:47-73.
Sieber, R., M. Collomb, A. Aeschlimann, P. Jelen, and H. Eyer. 2004 Impact of microbial cultures on conjugated linoleic acid in dairy products - A review. Int. Dairy J. 14:1-15.

Silva, R. A., M. S. F. Lima, J. B. M. Viana, V. S. Bezerra, M. C. B. Pimentel, A. L. F. Porto, M. T. H. Cavalcanti, and J. L. Lima Filho. 2012. Can artisanal "Coalho" cheese from Northeastern Brazil be used as a functional food? Food Chem. 135:1533-1538.

Siragusa, S., M. De Angelis, R. Di Cagno, C. G. Rizzello, R. Coda, and M. Gobbetti. 2007. Synthesis of g-aminobutyric acid by lactic acid bacteria isolated from a variety of Italian cheeses. Appl. Environ. Microbiol. 73:7283-7290.

Smacchi, E., and M. Gobbetti. 1998. Peptides from several Italian cheeses inhibitory to proteolytic enzymes of lactic acid bacteria, Pseudomonas fluorescens ATCC 948 and to the angiotensin I-converting enzyme. Enzyme Microb. Technol. 22:687-694.

Sonestedt, E., E. Wirfa“lt, P. Wallstro, B. Gullberg, M. Orho-Melander, and B. Hedblad. 2011. Dairy products and its association with incidence of cardiovascular disease: The Malmö diet and cancer cohort. Eur. J. Epidemiol. 26:609-618.

Sprong, R. C., A. J. Schonewille, and R. van der Meer. 2010. Dietary cheese whey protein protects rats against mild dextran sulfate sodium-induced colitis: Role of mucin and microbiota. J. Dairy Sci. 93:1364-1371.

Sullivan, A., C. Edlund, and C. Nord. 2001. Effect of antimicrobial agents on the ecological balance of human microflora. Lancet Infect. Dis. 1:101-114.

Tholstrup, T. 2006. Dairy products and cardiovascular disease. Curr. Opin. Lipidol. 17:1-10.

Tholstrup, T., C. E. Høy, L. N. Andersen, R. D. Christensen, and B. Sandstro"m. 2004. Does fat in milk, butter and cheese affect blood lipids and cholesterol differently? J. Am. Coll. Nutr. 23:169-176.

Tholstrup, T., B. Vessby, and B. Sandstrom. 2003. Difference in effect of myristic and stearic acid on plasma HDL cholesterol within 24 $\mathrm{h}$ in young men. Eur. J. Clin. Nutr. 57:735-742.

Timón, M. L., V. Parra, J. Otte, J. M. Broncano, and M. J. Petron. 2014. Identification of radical scavenging peptides $(<3 \mathrm{kDa})$ from Burgos-type cheese. Lebensm. Wiss. Technol. 57:359-365.

Torres-Llanez, M. J., A. F. González-Córdova, A. Hernández-Mendoza, H. S. García, and B. Vallejo-Córdoba. 2011. Angiotensinconverting enzyme inhibitory activity in Mexican Fresco cheese. J. Dairy Sci. 94:3794-3800.

Tujioka, K., M. Ohsumi, K. Horie, M. Kim, K. Hayase, and H. Yokogoshi. 2009. Dietary gamma-aminobutyric acid affects the brain protein synthesis rate in ovariectomized female rats. J. Nutr. Sci. Vitaminol. (Tokyo) 55:75-80.

Tvrzicka, E., L. S. Kremmyda, B. Stankova, and A. Zak. 2011. Fatty acids as biocompounds: their role in human metabolism, health and disease - A review. Part 1: Classification, dietary sources and biological functions. Biomed. Pap. Med. Fac. Univ. Palacky Olomouc Czech Repub. 155:117-130.

van Nieuwenhove, C. P., R. Oliszewski, S. N. Gonzalez, and A. B. P. Chaia. 2007. Conjugated linoleic acid conversion by dairy bacteria cultured in MRS broth and buffalo milk. Lett. Appl. Microbiol. 44:467-474

Wald, D. S., M. Law, and J. K. Morris. 2002. Homocysteine and cardiovascular disease: Evidence on causality from a meta-analysis. BMJ 325:1202.

Walther, B., A. Schimid, R. Sieber, and K. Wehrmüller. 2008. Cheese in nutrition and health. Dairy Sci. Technol. 88:389-405.

Wang, H. K., C. Dong, Y. F. Chen, L. M. Cui, and H. P. Zhang. 2010 A new probiotic cheddar cheese with high ACE-Inhibitory activity and g-aminobutyric acid content produced with koumiss-derived Lactobacillus casei Zhang. Food Technol. Biotechnol. 48:61-70.

Yang, B., H. Chen, Z. Gu, F. Tian, R. P. Ross, C. Staton, Y. Q. Chen, W. Chen, and H. Zhang. 2014. Synthesis of conjugated linoleic acid by the linoleate isomerase complex in food-derived lactobacilli. J. Appl. Microbiol. 117:430-439.

Yang, E., L. Fan, Y. Jiang, C. Doucette, and S. Fillmore. 2012. Antimicrobial activity of bacteriocin-producing lactic acid bacteria isolated from cheeses and yogurts. AMB Express 2:48. 
Yang, M., and M. E. Cook. 2003. Dietary conjugated linoleic acid decreased cachexia, macrophage tumor necrosis factor-alpha production, and modifies splenocyte cytokines production. Exp. Biol. Med. (Maywood) 228:51-58.

Yang, S. Y., F. X. Lu, Z. X. Lu, X. M. Bie, Y. Jiao, L. J. Sun, and B. Yu. 2008. Production of gamma-aminobutyric acid by Streptococcus salivarius subsp. thermophilus Y2 under submerged fermentation. Amino Acids 34:473-478.

Yasuda, S., N. Ohkura, K. Suzuki, M. Yamasaki, K. Nishiyama, H. Kobayashi, Y. Kadooka, and K. Igoshi. 2010. Effects of highly ripened cheese on HL-60 human leukemia cells: Antiproliferative activity and induction of apoptotic DNA damage. J. Dairy Sci. 93:1393-1400.
Yuan, J., K. Noratto, G. Munske, P. Pilla, I. Mohanty, D. A. Zapata, and G. Noratto. 2014. Potential of glycated proteins produced during aging of cheddar cheese to modulate fecal bacteria from obese mice ex vivo and protect against colon inflammation. FASEB J. 28:1018.5.

Yvon, M., and L. Rijnen. 2001. Cheese flavour formation by amino acid metabolism. Int. Dairy J. 11:185-201.

Zeppa, G., L. Conterno, and V. Gerbi. 2001. Determination of organic acids, sugars, diacetyl, and acetoin in Cheese by high-performance liquid chromatography. J. Agric. Food Chem. 49:2722-2726.

Zuljan, F. A., P. Mortera, S. H. Alarcón, V. S. Blancato, M. Espariz, and C. Magni. 2016. Lactic acid bacteria decarboxylation reactions in cheese. Int. Dairy J. 62:53-62. 